\title{
Review
}

\section{Familial Hypercholesterolemia and the Founder Effect Among Franco-Americans: A Brief History and Call to Action}

\author{
Reed Mszar, BS, ${ }^{a}$ Sara Buscher, BS, ${ }^{b}$ Heidi L. Taylor, PhD, ${ }^{c}$ Mary T. Rice-DeFosse, $\mathrm{PhD},{ }^{\mathrm{d}}$ and \\ Dervilla McCann, MD, MPH, FACC \\ ${ }^{a}$ Department of Chronic Disease Epidemiology, Yale School of Public Health, New Haven, Connecticut, USA \\ ${ }^{b}$ Division of General Pediatrics, Boston Children's Hospital, Boston, Massachusetts \\ ${ }^{c}$ Department of Sociology, Bates College, Lewiston, Maine, USA \\ ${ }^{d}$ Department of French and Francophone Studies, Bates College, Lewiston, Maine, USA \\ ${ }^{e}$ Department of Cardiology, Central Maine Medical Center, Lewiston, Maine, USA
}

\begin{abstract}
Familial hypercholesterolemia $(\mathrm{FH})$ is an inherited disorder characterized by chronically elevated low-density lipoprotein cholesterol levels and an increased risk of premature atherosclerotic cardiovascular disease. FH has been shown to disproportionately affect French Canadians and other ethnic populations due to the presence of a founder effect characterized by reduced genetic diversity resulting from relatively few individuals with $\mathrm{FH}$-causing genetic mutations establishing selfcontained populations. Beginning in the mid-1800s, approximately 1 million French Canadians immigrated to the Northeastern United States and largely remained in these small, tight-knit communities. Despite extensive genetic- and population-based research involving the FrenchCanadian founder population, primarily in the Province of Quebec, little is known regarding Franco-Americans in the United States. Concurrent with addressing the underdiagnosis rate of $\mathrm{FH}$ in the general population, we propose the following steps to leverage this founder effect and meet the cardiovascular needs of Franco-Americans: (1) increase cascade
\end{abstract}

Familial hypercholesterolemia $(\mathrm{FH})$ is an autosomal dominant genetic disorder of lipid metabolism that affects approximately 1 in every 250 individuals, representing nearly 1.3 million people in the United States. ${ }^{1,2}$ Heterozygous FH is characterized by lifelong elevated low-density lipoprotein cholesterol (LDL-C) levels and an increased risk of premature atherosclerotic cardiovascular disease (ASCVD) that is 20 times higher than the national average. ${ }^{2-5}$ Although $\mathrm{FH}$ can be

Received for publication December 28, 2019. Accepted January 19, 2020.

Ethics Statement: The research reported has adhered to the relevant ethical guidelines.

Corresponding author: Reed Mszar, Department of Chronic Disease Epidemiology, Yale School of Public Health, 60 College St., New Haven,

Connecticut 06510, USA. Tel: +1-703-300-1561.

E-mail: reed.mszar@yale.edu

See page 166 for disclosure information.

\section{RÉSUMÉ}

L'hypercholestérolémie familiale (HF) est un trouble génétique caractérisé sur un mode chronique par des taux élevés de cholestérol à lipoprotéines de faible densité et un risque accru de maladie cardiovasculaire athéroscléreuse prématurée. L'HF touche de façon disproportionnée les Canadiens français et d'autres groupes ethniques par suite d'un effet fondateur caractérisé par une faible diversité génétique résultant d'un nombre relativement peu élevé d'individus ayants des mutations génétiques responsables de l'HF établissant des populations isolées. À partir du milieu des années 1800 , environ un million de Canadiens français ont émigré dans la région nord-est des États-Unis et y sont pour la plupart demeurés au sein de communautés relativement restreintes et fortement homogènes. En dépit d'une vaste recherche génétique et populationnelle visant la population fondatrice canadienne-française, principalement dans la province de Québec, on sait peu de choses sur les Franco-Américains aux États-Unis. Parallèlement à une démarche ciblant le sous-diagnostic de l'HF au sein de

effectively managed with lipid-lowering agents such as statins, approximately $90 \%$ of those affected remain undiagnosed. ${ }^{2}$ If left untreated, men with $\mathrm{FH}$ have a $50 \%$ increased risk of experiencing a cardiac event by age 50 years, whereas untreated women have a $30 \%$ greater risk by age 60 years. ${ }^{4,6}$ Homozygous $\mathrm{FH}$, on the other hand, is a rare disease that has been estimated to affect between 1 in every 160,000 to 300,000 individuals. ${ }^{7}$ Untreated homozygous FH patients with severely elevated LDL-C levels develop significant atherosclerosis before the age of 20 years, and generally do not survive longer than 30 years.

\section{Familial Hypercholesterolemia Founder Effect}

Although FH affects all races and ethnicities, certain subpopulations experience $\mathrm{FH}$ at a higher frequency due to the presence of a founder effect. ${ }^{9}$ This particular phenomenon is 
screening in regions of the United States with a high proportion of individuals of French-Canadian descent; (2) promote registry-based, epidemiological research to elucidate accurate prevalence estimates as well as diagnostic and treatment gaps in Franco-Americans; and (3) validate contemporary risk stratification strategies such as the Montreal-FH-SCORE to enable optimal lipid management and prevention of premature atherosclerotic cardiovascular disease among French-Canadian descendants.

characterized by the loss of genetic variability that arises when the migration of relatively few individuals carrying a high frequency of FH-causing genetic mutations establish a new population and live in relative geographic and cultural isolation. ${ }^{10}$ In addition to French Canadians, other FH founder populations that have been identified include Ashkenazi Jews, Christian Lebanese, Finns, and South African Afrikaners. ${ }^{10-14}$ In most of these founder populations, the observed founder effects can be accounted for by relatively few mutations. ${ }^{15}$ In the context of French Canadians in the Province of Quebec, the number of different genetic mutations has provided compelling rationale for conducting genetic testing in clinical and research settings. ${ }^{16}$ The presence of this identified FH founder effect confers key advantages including the facilitation of early screening, comprehensive genetic counseling, and effective lipid-lowering treatment. ${ }^{17}$

Early research on the genetic basis of $\mathrm{FH}$ included a unique focus on the French-Canadian subpopulation. In 1987, Hobbs and colleagues ${ }^{9}$ first reported on the significant deletion in the low-density lipoprotein receptor $(L D L R)$ gene in approximately $63 \%$ of French Canadians with heterozygous $\mathrm{FH}$, citing that an $L D L R$ deletion had not been observed in any other ethnic group at the time. The authors, including Nobel laureates Brown and Goldstein, noted that this highfrequency $L D L R$ mutation was likely associated with a founder effect among the ancestors of present-day French Canadians and that the FH-causing genetic mutations are more severe than the ones observed throughout the general population. ${ }^{9}$ Furthermore, evidence suggests that 11 distinct mutations in the LDLR gene occur in more than $90 \%$ of all French-Canadian FH cases, with 6 of the mutations accounting for more than $85 \%$ of FH cases. ${ }^{9,15,18,19}$ It is theorized that the mutations occurring in relatively lower frequencies were either introduced after French migration or evolved as novel mutations. ${ }^{15}$

Even decades after the founder effect was observed in the French-Canadian population, a significant gap in $\mathrm{FH}$ knowledge and research persists regarding the approximately 2.4 million Franco-Americans currently living in the United States, many of whom are direct descendants of the original French settlers to Nouvelle France (present-day Province of Quebec). ${ }^{20}$ In this review, we recognize the wealth of research that has focused on French Canadians as a higher risk FH founder subpopulation and assert that Franco-Americans have been largely excluded from $\mathrm{FH}$ research and are suspected to la population générale, nous proposons les mesures suivantes pour tirer parti de cet effet fondateur et répondre aux besoins cardiovasculaires des Franco-Américains: 1) augmenter le dépistage en cascade sur les régions des États-Unis comptant une forte proportion de personnes d'ascendance canadienne-française; 2) promouvoir la recherche épidémiologique fondée sur les registres pour obtenir des estimations précises de la prévalence et cerner les lacunes touchant le diagnostic et le traitement chez les Franco-Américains; 3) valider les stratégies contemporaines de stratification du risque comme celle fondée sur le Montreal-FH-SCORE pour permettre la prise en charge optimale de la lipidémie et la prévention des maladies cardiovasculaires athéroscléreuses prématurées chez les descendants canadiensfrançais.

represent a substantial population presently undiagnosed and undertreated for FH. Therefore, we propose the following measures to begin addressing these gaps in research and care in concordance with ongoing population-level initiatives and multi-society recommendations: (1) increase cascade screening in regions of the United States with a high proportion of French-Canadian descendants; (2) promote registry-based, epidemiological research to elucidate accurate prevalence estimates as well as diagnostic and treatment gaps; and (3) validate risk stratification strategies such as the Montreal-FHSCORE to enable optimal lipid management and prevention of premature ASCVD in Franco-Americans (Fig. 1).

\section{Origins of Franco-Americans and Acadians}

To understand the origins of the founder effect among Franco-Americans, it is critical to first discuss the history of French Canadians and early French immigration to North America. The first French colony, Acadie or Acadia, was founded in 1604 in what are now Eastern Canada's Maritime provinces. Spanning the 17 th and 18 th centuries, a net migration of approximately 20,000 French people to a second, separate colony, Nouvelle France (New France), led to the establishment of Quebec City along with a rapid increase in the region's European population. ${ }^{16,21}$ Despite the signing of the Treaty of Paris later in 1763, allowing French colonists safe return to France following the Seven Years' War, the means for doing so were severely limited. As a result, most French settlers-by then numbering approximately 70,000 - remained in the colonies of North America. ${ }^{21,22}$

Demographics, family structures, and migration patterns significantly contributed to the unique history of French Canadians in Nouvelle France. Despite participation in a common migratory enterprise, men and women often emigrated from different French communities with men frequently travelling further distances. ${ }^{21}$ One notable example of sex-based differences in migration and settlement patterns occurred from 1663 to 1673 , when King Louis XIV sponsored the immigration of approximately 800 women known as the filles $d u$ roi-or the "King's Daughters"- to increase the population of the French colonies, level the gender imbalance, and compete with the rival English colonies of the time. $^{23}$ This was to be accomplished by marrying former infantry members of the French Carignan-Salières Regiment who remained in the region after conflicts with the Mohawks, 


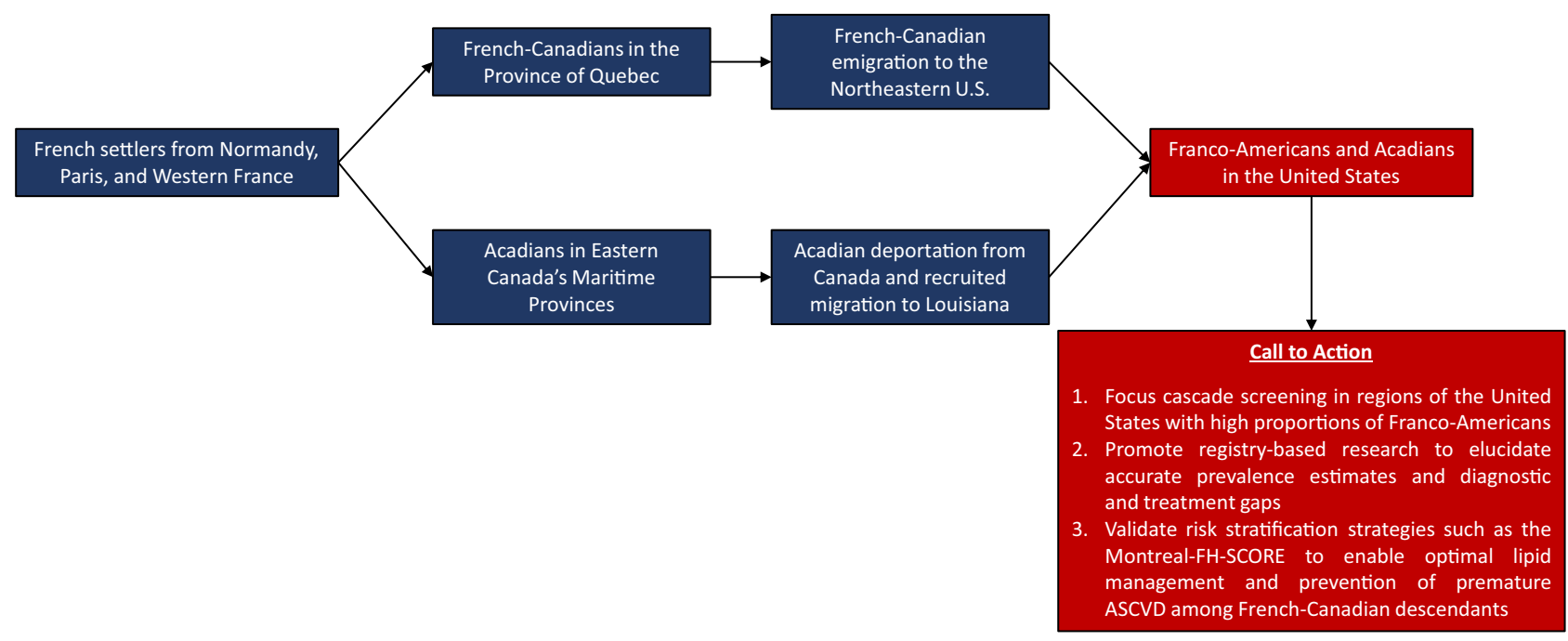

Figure 1. Summarized representation of the origins of the Franco-American founder subpopulation and proposed recommendations for the diagnosis and treatment of familial hypercholesterolemia $(\mathrm{FH})$ and prevention of premature atherosclerotic cardiovascular disease (ASCVD).

an Iroquoian-speaking indigenous people of North America and the easternmost tribe of the Iroquois Confederacy. ${ }^{21}$ Geographic and cultural isolation combined with early marriages, high birth rates, and relatively little exposure to other ethnic populations in Nouvelle France, ultimately reduced the genetic diversity at the time, thereby promoting endogamy and an augmentation of the consequences of the observed founder effect. ${ }^{17,24}$

Between 1840 and 1930, overpopulation in rural areas of the Province of Quebec, as well as economic power imbalances and political uprisings between French and English speakers, led to the emigration of more than 1 million French Canadians from Canada to the United States. Specifically, these migrants sought employment opportunities and greater financial security primarily in the New England textile mills at the height of the American Industrial Revolution. ${ }^{17}$ Across the Northeastern United States, French-Canadians began forming self-contained communities known as "Little Canadas" which were often situated near rapidly growing mill towns such as Manchester, New Hampshire; Burlington, Vermont; and Lewiston, Maine. French-Canadians also settled further south in growing industrial towns including Woonsocket, Rhode Island; Lowell, Massachusetts; Bridgeport, Connecticut; and throughout New York. Approximately two-thirds of these French-Canadian immigrants ultimately remained in the United States. ${ }^{21}$

Although French-Canadian descendants represent a significant ethnic population in the Northeastern United States, it is critical to also discuss the history of Acadians as a demographic with similar French origins and interrelated migration patterns. After their settlement in Acadia-what is now known as the Maritime provinces of Nova Scotia, New Brunswick, and Prince Edward Island, along with part of Quebec and Northern Maine-Acadians lived in relative geographic and political autonomy from the nearby French colony of Nouvelle France. Fearing an alignment with the French during the French and Indian War, British forces carried out the "Great Expulsion" (Le Grand Derangement) of the Acadians between 1755 and 1764 .
Many of the Acadians who did not perish during this deportation, were expelled to British-American colonies, England, and France, where a sizeable proportion were ultimately recruited by the Spanish government to migrate to presentday Louisiana. After the British victory during the Seven Years' War, the descendants of the exiled Acadian population gradually developed what is presently known as Cajun culture. $^{25}$ Other Acadians sought refuge from deportation by moving further into the hinterland of Nova Scotia and what is now considered Northern Maine (St. John Valley) and New Brunswick, and previously separated deportees managed to rejoin these often-isolated communities. Later on, Acadians from the Maritime provinces and Northern Maine migrated south to the industrial centers of New England and joined French-speaking counterparts.

Extensive genealogic records characterizing early migration patterns and subsequent isolation during the political environment of the time, combined with contemporary genetic evidence, serve as significant markers for the presence of a founder effect among French Canadians. ${ }^{16}$ Recently, Han and colleagues ${ }^{25}$ provided an intriguing historical representation of North America after European migration and settlement based on the genotypes of 770,000 individuals and distinct clustering patterns (Fig. 2). Considering that French immigration to Canada in the 17th and 18th centuries can be viewed as a mirror image of French-Canadian immigration to the United States in the 19th century, it is reasonable to suspect that corresponding founder effects with regional clustering among present-day Franco-Americans persist. ${ }^{21}$

\section{A Prototype for Focused Cascade Screening}

Cascade screening has been shown to be the most efficacious method for identifying additional cases, given the autosomal dominant inheritance nature of $\mathrm{FH}^{2}$ The Centers for Disease Control and Prevention classified cascade screening for $\mathrm{FH}$ as a tier 1 genomic application; therefore prioritizing this unique demographic in contemporary screening efforts could serve as a powerful prototype for 
6-9 Generations ago (1649-1791 AD)

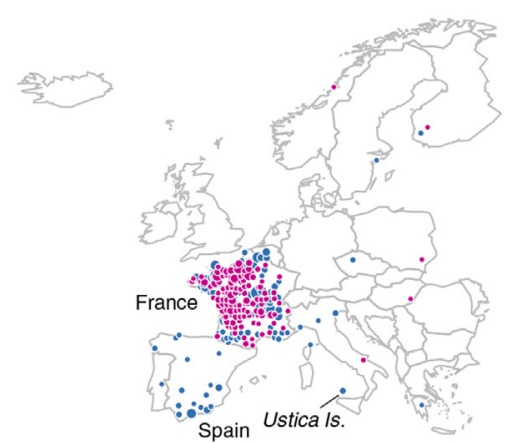

3-5 Generations ago (1785-1878 AD)

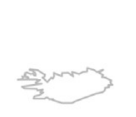

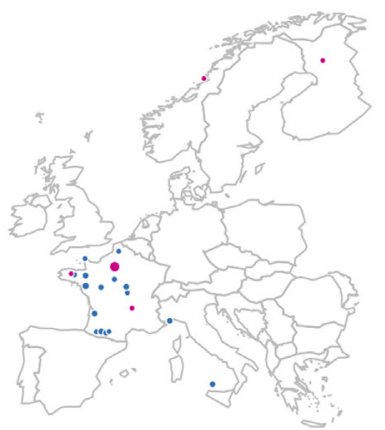

0-2 Generations ago (1882-1962 AD)
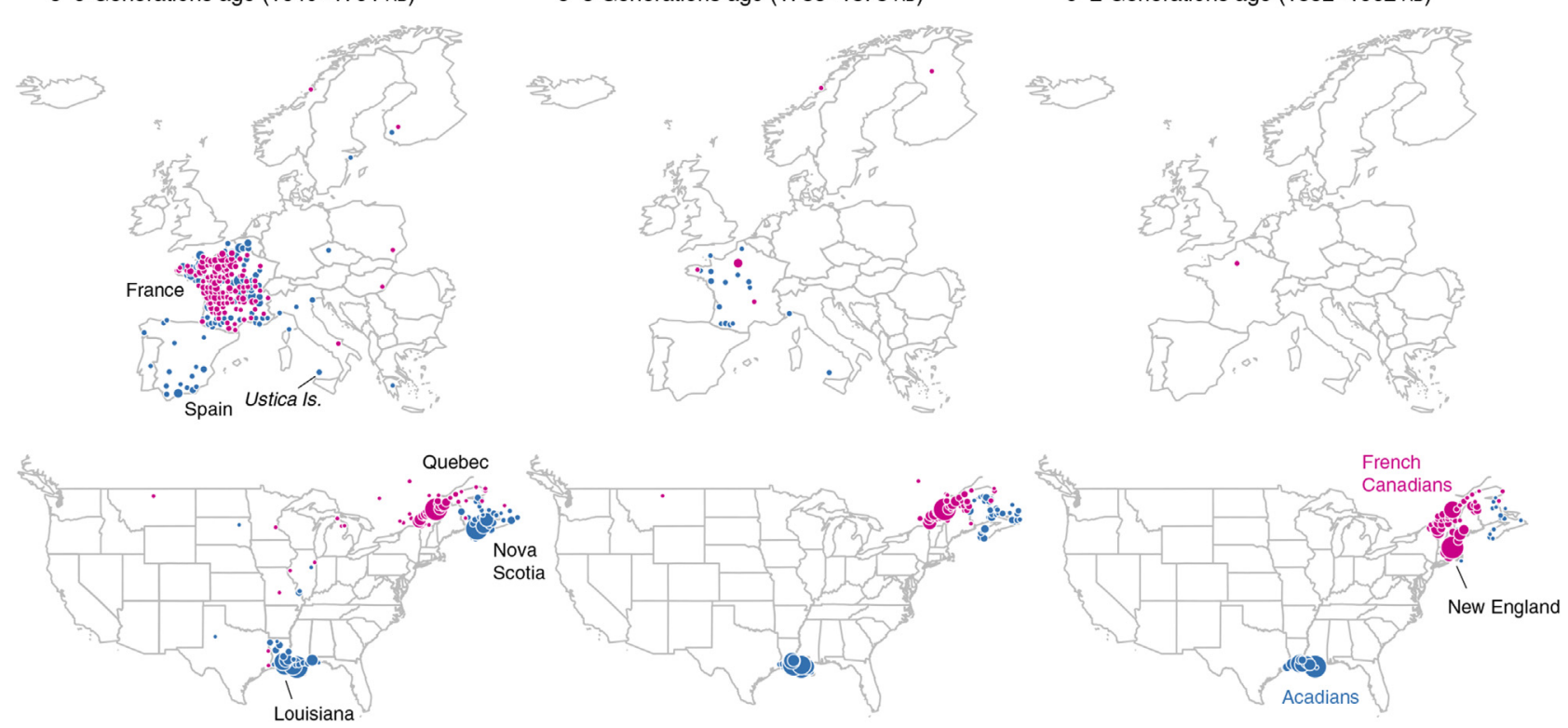

Figure 2. Genealogical origins of Cajuns/Acadians in Atlantic Canada (blue) and migration of French-Canadians (magenta) to the United States. Reproduced from Han et al., ${ }^{25}$ and data were made available in the public domain (Creative Commons $\mathrm{CCO}$ ).

high-yield case identification. ${ }^{26}$ Recent studies have shown that 3.3 years of life are gained for each new FH case diagnosed along with an incremental cost-effectiveness ratio of $\$ 2500$ to $\$ 4500$ per quality-adjusted life-year gained. ${ }^{26-28}$ In founder populations with a higher relative frequency of $\mathrm{FH}$ cases, screening is likely to produce a greater yield and be even more cost-effective than screening in the general population. ${ }^{2}$

Considering the extensive research regarding $\mathrm{FH}$-causing genetic mutations in French-Canadian cohorts and the shortage of studies conducted in Franco-Americans, we first

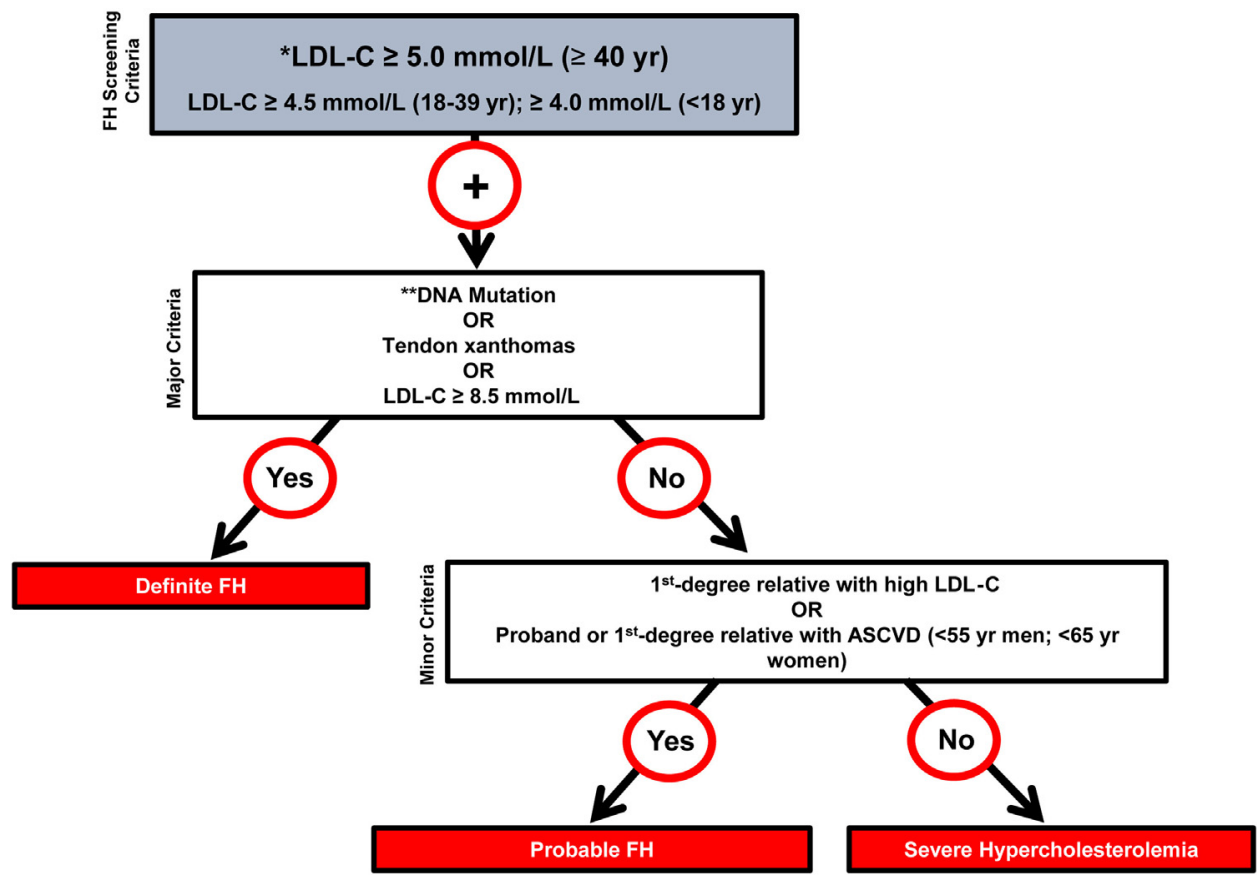

Figure 3. Canadian definition for the clinical diagnosis of FH. Secondary causes of high LDL-C should be ruled out (severe or untreated hypothyroidism, nephrotic syndrome, hepatic disease [biliary cirrhosis], and medication, especially antiretroviral agents). $* *$ Causal DNA mutation refers to the presence of a known FH-causing variant in the LDLR, APOB, or PCSK9 gene on the basis of presence of the variant in ClinVar, the Human Gene Mutation Database, or Western Database of Lipid Variants databases, in the proband or a first-degree relative. ASVD, atherosIcerotic vascular disease; LDL-C, low-density lipoprotein cholesterol. Reproduced from Ruel et al. ${ }^{29}$ with permission of Elsevier. 
assert that screening efforts should be increased in regions of the United States with a high proportion of individuals of French-Canadian descent, thereby initiating cascade screening in first-degree relatives of identified $\mathrm{FH}$ probands. Ruel and colleagues ${ }^{29}$ recently developed a simplified definition for diagnosing FH based on LDL-C levels dependent on age, the presence of a genetic mutation or tendon xanthomas, and a family history of elevated LDL-C or ASCVD (Fig. 3). The authors compared this strategy with other diagnostic criteria such as the Simon Broome Register and Dutch Lipid Clinic Network and found that, when assessed in 5987 Canadians, the new algorithm displayed strong agreement with the alternative methods. ${ }^{29}$ Evaluating the external validity of this particular approach that has been assessed among Canadians is critical in identifying and diagnosing Franco-American proband patients and subsequently initiating cascade or family screening.

\section{Registry-Based Epidemiological Research}

Second, we emphasize the importance of conducting registry-based, epidemiological research to produce accurate prevalence estimates of disease burden as well as potential diagnostic and treatment gaps in Franco-Americans. Prior research has elucidated that the prevalence of $\mathrm{FH}$ in the Province of Quebec is twice that observed in most population samples. ${ }^{17}$ At the time of the 1981 census, regional frequency estimates were approximated to be as high as 1:154 for Northeastern Quebec and 1:80 on the north shore of the St. Lawrence. $^{16,30}$ On the basis of initial results from the Canadian FH Registry and a recent meta-analysis on the prevalence of $\mathrm{FH}$, it has been estimated that there are approximately 145,000 individuals with FH in Canada. ${ }^{31,32}$ The Canadian Cardiovascular Society has indicated that the potential advantages of the use of $\mathrm{FH}$ registries include the ability to monitor the effectiveness of lipid-lowering therapies over time, to establish a database for relevant clinical trials and research, and to provide regional-level prevalence data. This information would offer critical insights into the current status and disease burden of higher frequency founder subpopulations and could reveal parallels with previously observed epidemiological trends over time. ${ }^{8}$ Updated prevalence estimates from the Canadian FH Registry are likely imminent. ${ }^{16}$

In the United States, the corresponding Cascade Screening for Awareness and Detection (CASCADE) FH Registry was originally developed and is currently led by the FH Foundation and consists of approximately 5000 patients with $\mathrm{FH}$ recruited from 35 lipid specialty clinics across the country. ${ }^{33}$ Using data from this national registry could be instrumental in characterizing the specific burden of FH among Franco-Americans and identifying potential disparities in care. Moreover, forming and sustaining global collaborations with patient-centered organizations, medical societies, and other key stakeholders is essential in advancing research and clinical care, not only for FrancoAmericans and French Canadians, but also for other high-risk subpopulations and all those affected by $\mathrm{FH}$ worldwide. $^{34}$

\section{Validation of the Montreal-FH-SCORE}

Last, we urge the validation of risk-stratification strategies such as the Montreal-FH-SCORE in Franco-Americans. This method was originally developed in a cohort of French $\mathrm{Ca}$ nadians with a causal genetic FH mutation to stratify patients with a high ASCVD risk. Upon screening more than 20,000 patients with dyslipidemia and identifying 670 subjects carrying a causal mutation in the $L D L R$ gene, Paquette and colleagues $^{16,35}$ found that FH subjects with a high MontrealFH-SCORE score $(>20)$ have a 10.3-fold higher odds of presenting ASCVD events compared with subjects in the lower score group.

An independent, external validation study confirmed that this risk prediction score was a strong predictor of prevalent ASCVD in French Canadians with FH and that adding lipoprotein(a) offers a modest improvement in the discrimination of the resulting score. ${ }^{36}$ In the updated Canadian Cardiovascular Society Position Statement on Familial Hypercholesterolemia, the authors note that the Montreal-FH-SCORE may be beneficial for use among adult patients with $\mathrm{FH}$ requiring further stratification of their ASCVD risk. ${ }^{8}$ Continued validation studies - on both a national and an international scale-are crucial in determining whether this risk stratification score can be applied to Franco-Americans as descendants of the original FrenchCanadian founder subpopulation.

\section{Conclusions}

With approximately 2.4 million individuals reporting a French-Canadian ancestry in the United States, leveraging the advantages conferred by the presence of this suspected founder effect may help to facilitate focused cascade screening, enhance treatment with lipid-lowering therapies, and prevent premature ASCVD in a high-risk demographic. In concordance with contemporary recommendations and initiatives from the Canadian Cardiovascular Society ${ }^{8}$ and representatives of the Global $\mathrm{FH}$ community such as the FH Foundation and the World Heart Federation, ${ }^{34}$ we highlight the importance of and urgency for FrancoAmericans, as an understudied demographic, to be further included in the proposed recommendations for funding $\mathrm{FH}$ registries, raising awareness for $\mathrm{FH}$, developing family-based care plans, and screening for and diagnosing $\mathrm{FH}$.

Furthermore, we recommend that: (1) cascade screening for $\mathrm{FH}$ be enhanced in specific regions of the United States with higher proportions of French-Canadian descendants, including the Northeast; (2) registry-based, epidemiological research strive to produce accurate prevalence estimates and identify potential diagnostic and treatment gaps in FrancoAmericans; and (3) that contemporary risk stratification strategies such as the Montreal-FH-SCORE be validated to assess ASCVD risk for effective lipid management in this at-risk subpopulation. While there is indeed an urgent need to screen, diagnose, and treat FH in all those affected, FrancoAmericans, as direct descendants of the known FrenchCanadian founder population, represent a unique and understudied demographic. Future research should strive to 
examine whether novel genetic mutations exist in FrancoAmericans based on their particular history and migration to the United States.

\section{Acknowledgements}

The authors thank the FH Foundation along with other members of the Global FH community for their important work advancing awareness of $\mathrm{FH}$, promoting multidisciplinary research, and producing evidence-based public policies to help affected individuals and their families. The authors also thank Professor Leslie P. Choquette for her insightful comments on the historical origins of Franco-Americans in the United States.

\section{Funding Sources}

There are no funding sources to declare.

\section{Disclosures}

The authors have no conflicts of interest to disclose.

\section{References}

1. Goldstein JL, Brown MS. The LDL receptor. Arterioscler Thromb Vasc Biol 2009;29:431-8.

2. Gidding SS, Champagne MA, de Ferranti SD, et al. The Agenda for Familial Hypercholesterolemia: a Scientific Statement from the American Heart Association. Circulation 2015;132:2167-92.

3. Goldberg AC, Hopkins PN, Toth PP, et al. Familial hypercholesterolemia: screening, diagnosis and management of pediatric and adult patients: clinical guidance from the National Lipid Association Expert Panel on Familial Hypercholesterolemia. J Clin Lipidol 2011;5:S1-8.

4. Nordestgaard BG, Chapman MJ, Humphries SE, et al. Familial hypercholesterolaemia is underdiagnosed and undertreated in the general population: guidance for clinicians to prevent coronary heart disease: consensus statement of the European Atherosclerosis Society. Eur Heart J 2013;34:3478-90a.

5. Wiegman A, Gidding SS, Watts GF, et al. Familial hypercholesterolaemia in children and adolescents: gaining decades of life by optimizing detection and treatment. Eur Heart J 2015;36:2425-37.

6. McGowan MP, Hosseini Dehkordi SH, Moriarty PM, Duell PB. Diagnosis and treatment of heterozygous familial hypercholesterolemia. J Am Heart Assoc 2019;8:e013225.

7. Cuchel M, Bruckert E, Ginsberg HN, et al. Homozygous familial hypercholesterolaemia: new insights and guidance for clinicians to improve detection and clinical management. A position paper from the Consensus Panel on Familial Hypercholesterolaemia of the European Atherosclerosis Society. Eur Heart J 2014;35:2146-57.

8. Brunham LR, Ruel I, Aljenedil S, et al. Canadian Cardiovascular Society Position Statement on Familial Hypercholesterolemia: Update 2018. Can J Cardiol 2018;34:1553-63.

9. Hobbs HH, Brown MS, Russell DW, Davignon J, Goldstein JL. Deletion in the gene for the low- density-lipoprotein receptor in a majority of French Canadians with familial hypercholesterolemia. N Engl J Med 1987;317:734-7.

10. Austin MA, Hutter CM, Zimmern RL, Humphries SE. Genetic causes of monogenic heterozygous familial hypercholesterolemia: a HuGE Prevalence Review. Am J Epidemiol 2004;160:407-20.
11. Seftel HC, Baker SG, Jenkins T, Mendelsohn D. Prevalence of familial hypercholesterolemia in Johannesburg Jews. Am J Med Genet 1989;34: 545-7.

12. Rubinsztein DC, Coetzee GA, Marais AD, et al. Identification and properties of the proline664-leucine mutant LDL receptor in South Africans of Indian origin. J Lipid Res 1992;33:1647-55.

13. Koivisto UM, Turtola H, Aalto-Setala K, et al. The familial hypercholesterolemia (FH)-North Karelia mutation of the low density lipoprotein receptor gene deletes seven nucleotides of exon 6 and is a common cause of FH in Finland. J Clin Invest 1992;90:219-28.

14. Fahed AC, Safa RM, Haddad FF, et al. Homozygous familial hypercholesterolemia in Lebanon: a genotype/phenotype correlation. Mol Genet Metab 2011;102:181-8.

15. Couture P, Morissette J, Gaudetd D, et al. Fine mapping of low-density lipoprotein receptor gene by genetic linkage on chromosome 19p13.1p13.3 and study of the founder effect of four French Canadian lowdensity lipoprotein receptor gene mutations. Atherosclerosis 1999;143: $145-51$.

16. Paquette M, Genest J, Baass A. Familial hypercholesterolemia: experience from the French-Canadian population. Curr Opin Lipidol 2018;29: 59-64.

17. Davignon J, Roy M. Familial hypercholesterolemia in French-Canadianstaking advantage of the presence of a "founder effect". Am J Cardiol 1993;72:6D-10D.

18. Couture P, Vohl MC, Gagné C, et al. Identification of three mutations in the low-density lipoprotein receptor gene causing familial hypercholesterolemia among French Canadians. Hum Mutat 1998;(Suppl 1): S226-31.

19. Simard J, Moorjani S, Vohl M-C, et al. Detection of a novel mutation (stop 468) in exon 10 of the low-density lipoprotein receptor gene causing familial hypercholesterolemia among French Canadians. Hum Mol Genet 1994;3:1689-91.

20. Brittingham A, Patricia de la Cruz G. Ancestry: 2000, Census 2000 Brief. Washington, DC: US Census Bureau, 2004.

21. Choquette L. Frenchmen into Peasants: Modernity and Tradition in the Peopling of French Canada. Cambridge, MA: Harvard University Press, 1997.

22. Parkman F. France and England in North America. Vol 1. New York: Library of America, 1983.

23. Landry Y. Orphelines en France pionnières au Canada: Les filles du roi au XVIIe siècle. Montreal: Leméac Éditeur Inc., 1992.

24. Bouchard G, Braekeleer MD. Homogénéité ou diversité? L'histoire de la population du Québec revue à travers ses gènes. Hist Soc/Soc Hist 1990;23:325-61.

25. Han E, Carbonetto P, Curtis RE, et al. Clustering of 770,000 genomes reveals post-colonial population structure of North America. Nat Commun 2017;8:14238.

26. Knowles JW, Rader DJ, Khoury MJ. Cascade screening for familial hypercholesterolemia and the use of genetic testing. JAMA 2017;318: $381-2$.

27. Nherera L, Marks D, Minhas R, Thorogood M, Humphries SE. Probabilistic cost-effectiveness analysis of cascade screening for familial hypercholesterolaemia using alternative diagnostic and identification strategies. Heart 2011;97:1175-81. 
28. Wonderling D, Umans-Eckenhausen MAW, Marks D, et al. Costeffectiveness analysis of the genetic screening program for familial hypercholesterolemia in the Netherlands. Semin Vasc Med 2004;4:97-104.

29. Ruel I, Brisson D, Aljenedil S, et al. Simplified Canadian definition for familial hypercholesterolemia. Can J Cardiol 2018;34:1210-4.

30. Moorjani S, Roy M, Gagne C, et al. Homozygous familial hypercholesterolemia among French-Canadians in Québec Province. Arteriosclerosis 1989;9:211-6.

31. Brunham LR, Ruel I, Khoury E, et al. Familial hypercholesterolemia in Canada: initial results from the FH Canada national registry. Atherosclerosis 2018;277:419-24.

32. Akioyamen LE, Genest J, Shan SD, et al. Estimating the prevalence of heterozygous familial hypercholesterolaemia: a systematic review and meta-analysis. BMJ Open 2017;7:e016461.
33. O'Brien EC, Roe MT, Fraulo ES, et al. Rationale and design of the familial hypercholesterolemia foundation CAscade SCreening for Awareness and DEtection of Familial Hypercholesterolemia registry. Am Heart J 2014;167:342-9.e317.

34. Wilemon KA, Patel J, Aguilar-Salinas C, et al. Reducing the clinical and public health burden of familial hypercholesterolemia. JAMA Cardiol 2020 Jan 2 [Epub ahead of print].

35. Paquette M, Dufour R, Baass A. The Montreal-FH-SCORE: a new score to predict cardiovascular events in familial hypercholesterolemia. J Clin Lipidol 2017;11:80-6.

36. Paquette M, Brisson D, Dufour R, et al. Cardiovascular disease in familial hypercholesterolemia: validation and refinement of the MontrealFH-SCORE. J Clin Lipidol 2017;11:1161-7 e1163. 